\title{
Internal medicine, art and science in the third millennium
}

\author{
FÉLIX MUÑOZ C.
}

\begin{abstract}
Internal medicine, art and science in the third millennium is a statement that Medicine is not only science. It acts on the sick individual to reestablish a natural state as a curative art. Medical art, commissioned by an individual or a society, is service. It requires vocation to obtain satisfaction. However due to the incidence of value changes, market globalization, technological and industrial development, the patient/physician relationship is becoming a user/provider relationship. Physician-related factors such as a higher health care demand, resource shortage and a progressive specialization have also influenced this change of paradigm. This is causing dissatisfaction, loss of self-esteem and a lower ethical commitment among professionals. We need to recover a professional repertoire of ideas in the context of a global ethics. Responsibility and co-responsibility are ethical principles addressed to technological civilizations and their collateral effects on people and environment that lead to a "responsible globalization". We also need a scientific futurology to define risks and avoid errors. In this era of progressive specialization, Internal Medicine, with its holistic vision of mankind, may play a fundamental role in the field of bioethics.
\end{abstract}

(Rev Med Chile 2013; 141: 217-219).

Key words: Congresses as Topic; History, $21^{\text {st }}$ Century; Internal Medicine.

\section{Medicina interna, arte y ciencia en el tercer milenio}

"Medicina Interna, Arte y Ciencia en el Tercer Milenio", expresa que la medicina no es exclusivamente ciencia. Tiene de si actuar hábilmente sobre el hombre enfermo, (arte curativo), buscando restablecer un estado natural. El arte médico, comisionado por el enfermo o por la sociedad, es servicio. Requiere vocación, obteniendo su propia satisfacción. Sin embargo, la relación "paciente / médico", se ha visto transformada actualmente en "usuario / prestador", incidiendo factores generales, tales como cambios valóricos, preeminencia del mercado (globalización), desarrollo de la tecnología e industria, y además factores propiamente médicos: mayor demanda asistencial, escasez de recursos, progresiva especialización, presencia de gestores no médicos, y otros. Ello ha provocado en los médicos insatisfacción, pérdida de autoestima y menor compromiso ético. Necesitamos recuperar un ideario profesional, en el contexto de una "ética global". El "principio de la responsabilidad" (Jonas) o la "corresponsabilidad" (Apel), son éticas destinadas a la civilización tecnológica y a sus efectos colaterales sobre las personas y el medio ambiente, conducentes a una "globalización responsable". Necesitamos, además, estimular el desarrollo de una "futurología científica" que permita definir los riesgos a evitar o los errores a corregir. En esta era de creciente especialización, la Medicina Interna, beneficiaria de la mejor tradición médica por su visión holística del hombre, puede y debe jugar un rol fundamental en el campo de la Bioética. 


\section{A welcome to the authorities, guests, participants, attendants:}

First of all, I would like to welcome you and thank you all, for attending this XXXI World Congress of the International Society of Internal Medicine (ISIM) and the concurrent meeting of the Latin American Society of Internal Medicine (SOLAMI). Most especially, I would like to thank our international participants, who have travelled from far lands to come to Chile.

Six years ago in Taipei, the Sociedad Médica de Santiago - Chilean Society of Internal Medicine was awarded the opportunity to host the forthcoming World Congress, and today it gives me a great pleasure to inaugurate the XXXIst one, here in Santiago. The Congress will allow us to exchange knowledge, experience, and to establish professional bonds and ties of friendship, fully consistent with the bylaws and purposes of the ISIM. Our intention is to contribute also to Chilean and Latin American medicine and that is why we decided to incorporate the SOLAMI meeting, and to have some presentations in Spanish, in specific auditoriums.

\section{Inaugural speech}

The unifying topic of the Congress: "Internal Medicine, art and science in the Third Millennium", was chosen to represent the essential idea that medicine is not only scientific knowledge and truthseeking. It is about taking care of the sick by using a skill, a technique. The art of medicine, or the craft of curing, is not about creating something new. It is about re-establishing a state, not an artificial state -in fact- but a natural one, or as natural as it can be. The relationship between the art of medicine and its subject (the sick person), is a unique one. Medical science, like science in general, founds its purpose in knowledge, with which it seeks to support the doctor's healing capability.

Nevertheless, the practical art is not merely the application of basic theory, as such. It is not just "the unequivocal application, of unequivocal knowledge, over an unequivocal material (the patient), with an unequivocal end". It has to do with the specific case of each individual, with all its uniqueness and complexity, putting our judgment to a test on a daily basis. The art of medicine and its practice is learned with effort, and with a master, with whom you overcome the adversities, and learn life experiences. The medical act, either as a commissioner of the sick person, or the society, is service, devotion, where "the calling" is required. So, we are not far, from the poetic words of Rabindranath Tagore, in his "Inspiring Thoughts"1, when he says:

\section{I slept and dreamt that life was joy \\ I awoke and saw that life was service \\ I acted and behold service was joy}

However, since the end of the nineteen-sixties, we have been living in changing times. It has been a transition between two eras: modernity, and what is being called post-modernity, or post-industrial society; an era of globalization with a society in global risk. As a result, the utopias and meta-narratives forged by modernity have been discredited, leaving subject to question our perception of the world and of mankind.

Medical values have proved to be particularly sensitive to the exponential development of science and its technical applications, with subsequent specialization. The elemental relationship, "sick person /doctor" has also come to be affected by other factors, typical of our times: the increasing health care demand, the ways in which national health-care services are organized, the institutional norms, the scarcity of resources, presence of new non-medical actors, market pressures, the healthcare industry, and so on.

These emerging agents are transforming the above mentioned relationship into one of "client / service provider".

This new scenario has given rise to dissatisfaction and deterioration of our profession, with studies reporting low self-esteem, the primacy of economic interests, and less ethical commitment, among others. It has therefore become necessary to recover the professional ideology, and above all, promote and encourage the medical profession with a moral approach.

In today's society, the risk looms not only over medicine, but over the present and future of mankind and nature ${ }^{2-4}$. Consequently, wider ethical perspectives acquire importance, such as the Principle of Responsibility, of Hans Jonas ${ }^{4,5}$, or the Shared Responsibility, of Karl-Otto Apel ${ }^{6}$, in accordance with the advances of modern science and associated technology, and their side effects on humans and the environment.

We have warned that technical progress has 
made us vulnerable ${ }^{7}$. It is a fact that demands human responsibility, for the utmost consequences of our actions. We must also accept our responsibility for self-serving attitudes in the socio-political arena, and be aware that the great ethical dilemmas generated by modern society devolve upon social policy, as is particularly evident in the case of public health.

What we need, therefore, is a kind of "Global Ethics", that is, a moral guide to the process of globalization, one that takes cultural diversity into consideration, and facilitates social interaction. It is essential that we have universal values, values that control the consequences of techno-scientific progress (atomic radiation, genetic manipulation in man and other living creatures, and so on), given the risks that they represent to humanity.

It is becoming clear that we need to encourage the development of a kind of Scientific Futurology, one that defines the risks that should be avoid, or the mistakes that must be corrected, and point to a form of Responsible Globalization.

Contemporary ethics must find a basis for universally valid norms that respect differences in values.

In this era of growing specialization, Internal Medicine, beneficiary of the best medical tradition due to its holistic vision of the individual, can, and must play, a fundamental role in the field of bioethics.

Finally, I would like to thank you all for being here today and to participate in this event.

\section{References}

1. Tagore R. Inspiring Thoughts. Rajpal \& Sons. Delhi, 2011.

2. Beck U. World Risk Society. Blackwell Publishers, Ltd., 1999.

3. Cortina A. La ética de la sociedad civil. $4^{\mathrm{a}}$ Edición. Grupo Anaya, S.A. Madrid, 2000.

4. Jonas $\mathrm{H}$. El principio de la responsabilidad. Título original: Das Prinzip Verantwortung. Traducción: Javier Fernández. 2a Edición en castellano. Editorial Herder. España, 2004.

5. Jonas H. Técnica, medicina y ética. La práctica del principio de responsabilidad. Título original: Technik, medizin und Ethik. Zur Praxis des prinzips Verantwortung. Traducción: Carlos Fortea. Paidós, Barcelona, 1997.

6. Apel K-O. La globalización y una ética de la responsabilidad. Reflexiones filosóficas acerca de la globalización. Prometeo libros, Buenos Aires, 2007.

7. Muñoz FC. El principio de la responsabilidad en Hans Jonas y los principios y compromisos del profesionalismo médico. Tesis para optar al grado de Magíster en Filosofía. Universidad de Chile, Facultad de Filosofía. Santiago de Chile, 2008. 